\title{
Under the shadow of the Japanese cherry trees
}

\author{
Sob a sombra das cerejeiras japonesas
}

\author{
A la sombra de los cerezos japoneses
}

\begin{abstract}
ALL'OMBRA DEI CILIEGI GIAPPONESI. GORIZIA 1961. Slavich A. Merano: Edizioni Alphabeta Verlag; 2018. 271 p. ISBN: 978-88-7223-315-3.
\end{abstract}

doi: 10.1590/0102-311X00346820

The book's title originates from the trees along the avenue of the psychiatric hospital of Gorizia, under the shadow of which discussions and meetings took place at the very beginning of Italy's psychiatric revolution. The famous psychiatrist Franco Basaglia is regarded as the father of the Italian Law 180/1978 (the so-called Basaglia Law) that stated the asylum's closure and the institution of the psychiatric services on the territory. Antonio Slavich (1935-2009) was a student and his very first collaborator in Gorizia.

Basaglia became director of the psychiatric hospital in Gorizia in November 1961, while Slavich arrived just few months later, in March 1962. The book tells the story of those first months and years when the asylums' slow and progressive dismantling begins 1 .

The description of the Gorizia asylum at their arrival resembles the description of almost all the asylums in Italy at that time: the patients were grouped in large and squalid departments, furnished with a few benches and heavy tables; bodies were wrapped-up in canvases, gray and shaved; patients were tied to a bed or, in the shining days, to trees; many were lying on the ground or stone benches, or wandered aimlessly.
In that unchanging and miserable place, where violence was poorly disguised, every nonritual gesture - Slavich says - every little action that scratched the surface a bit seemed already like a reform. With emotion and passion, despite the choice to use the third person in the whole narration, the author recalls the small and great daily conquests: repainted walls, uniforms replaced by clothes, real plates and cutlery, meetings, open doors and car rides for those who had only been in an ambulance to get tied up in the asylum.

The author comments that big enterprises - even those full of meaning and destined to resound for a long time - often have a modest, almost minimalist start. As reported, the reform started and proceeded by trial and error, without an exact plan. But, from the very beginning, it had a clear final objective able to aggregate a progressively more significant number of collaborators first in Gorizia, then Trieste and many other Italian regions: to dismantle the practice of asylums, to place the ill person - not the illness - at the center of the medical efforts, to radically change the relationship between the health personnel and the patient, to recognize that the person suffering from psychiatric disorders is a citizen who is entitled to the same rights as the other people, to restore freedom and dignity to the patients.

The book, published posthumously, deserves to be read because it tells the facts at the origin of Law 180/1978. Students and people working in the field of psychiatry are the natural audiences 
for the book: they will be able to appreciate the history behind it, and at the same time to recognize the efforts to keep the spirit of the reform alive, inspiring them to radicalize and fulfill the reform even further.

The book is a perfect reading also for a wider audience of intellectually curious and vigilant readers, as the psychiatric reform in Italy has been not only a crucial reform for psychiatry but also a prominent example of civilization.

Alphabeta Verlag published the book in 2018 in the Series 180 (Critical Mental Health Archive), a beautiful way to celebrate the 40th anniversary of Law 180/1978, regarded as one of the most important laws in the history of the Italian Republic.

\section{Corinna Porteri 1}

1 IRCCS Istituto Centro San Giovanni di Dio Fatebenefratelli, Brescia, Italy.

cporteri@fatebenefratelli.eu

\section{Additional information}

ORCID: Corinna Porteri (0000-0001-7916-0530).

1. Slavich A. All'ombra dei ciliegi giapponesi. Gorizia 1961. Merano: Edizioni Alphabeta Verlag; 2018. 